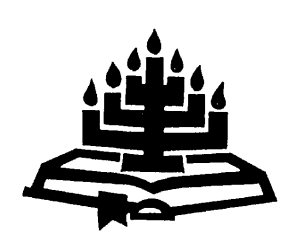

\title{
1 Konings 8: verskillende perspektiewe op God se teenwoordigheid
}

\author{
D.F. O'Kennedy \\ Dept. Ou en Nuwe Testament \\ Universiteit van Stellenbosch \\ STELLENBOSCH \\ E-pos: danieok@nghelder.co.za
}

Abstract:

1 Kings 8: Different perspectives on God's presence

1 Kings 8 is one of the most important chapters in Deuteronomic History. It originated over a long period of time and different authors/redactors were involved in the composition of this chapter. The text of 1 Kings 8 depicts several theological themes and this article focuses on the understanding of divine presence. Different perspectives on God's presence are portrayed: The ark, temple and cloud as symbols of divine presence; God dwells in heaven; God's Name is in the temple; God is omnipresent. The greater part of 1 Kings 8 comprises the temple dedication prayer of Solomon 11 Kings 8:22-53). Prayer is the act of worship by which the temple on earth (or the worshipper in the temple) and heaven meet each other.

\section{Opsomming}

1 Konings 8: verskillende perspektiewe op God se teenwoordigheid 1 Konings 8 is een van die belangrikste hoofstukke in die Deuteronomistiese Geskiedwerk. Dit het oor 'n lang tydperk ontstaan en verskillende skrywers/redaktors was by die samestelling van hierdie hoofstuk betrokke. Die teks van 1 Konings 8 verwys na verskeie teologiese temas en hierdie artikel fokus op die verstaan van Goddelike teenwoordigheid. Verskillende perspektiewe op God se teenwoordigheid kom in hierdie teksgedeelte voor: die ark, tempel en wolk as simbole van God se teenwoordigheid; God woon in die hemel; God se Naam is in die tempel; God is alomteenwoordig. Die grootste gedeelte van 1 Konings 8 bestaan uit die tempelwydingsgebed van Salomo 
(1 Kon. 8:22-53). Gebed is die manier waarop die tempel op aarde (of die bidder in die tempel) en hemel mekaar ontmoet.

\section{Inleiding}

Daar is ' $n$ hele aantal teologiese temas wat in 1 Konings 81 aangetref word: die teenwoordigheid van God; sonde, berou, bekering en vergifnis2; God se verbond met Dawid en sy huis; die verkiesing van Israel; ensovoorts. Een van die belangrikste teologiese temas in hierdie hoofstuk is die verstaan van Goddelike teenwoordigheid. Dit is juis om hierdie rede dat Brueggemann (1982:27) Hoofstuk 8:1-30 onder die opskrif "The battle for God's presence" bespreek. Die volgende vrae kan geopper word: Bespeur 'n mens in hierdie hoofstuk dalk uiteenlopende menings oor wat God se teenwoordigheid impliseer? Lewer die teks van 1 Konings 8 'n finale uitspraak oor watter perspektief nou eintlik "reg" is? Watter rol speel gebed in die siening oor God se teenwoordigheid?

In hierdie artikel sal gepoog word om moontlike antwoorde op bogenoemde vrae te bied. Eers sal 'n paar inleidende opmerkings oor die literêre en historiese agtergrond van 1 Konings 8 gemaak word voordat die verskillende perspektiewe bespreek word.

\section{Enkele literêre en historiese opmerkings oor 1 Konings 8}

\subsection{Opbou en struktuur}

1 Konings 8 vorm deel van die gedeelte in Konings wat spesifiek oor koning Salomo handel, die sogenaamde Salomo-narratief (1 Kon. $2: 12 b-11: 43) .{ }^{3}$ Hoofstuk 5-8 beskryf die bou van die tempel en paleis en sluit af met die inwyding van die tempel in 1 Konings 8.4

$1 \quad$ Daar kom ook 'n parallelle weergawe van die tempelwyding in 2 Kronieke 5:27:11 voor. In hierdie artikel word hoofsaaklik op 1 Konings 8 gefokus.

2 Vergelyk O'Kennedy (2000:72-88) vir 'n breedvoerige bespreking van vergifnis in 1 Konings 8:22-53.

3 Daar is verskil van mening oor die indeling van die Salomo-narratief. Die volgende standpunte word gehuldig: (1) 1 Konings 1-11 (Parker, 1988; Brettler, 1991); (2) 1 Konings 2:12b-11:43 (Long, 1984; Deist, 1986); (3) 1 Konings 3-11 (Porten, 1967; De Vries, 1985;); (4) 1 Konings 1-10 (Nelson, 1987); (5) 1 Konings 1-12:24 (Frisch, 1991).

4 Deist (1986:80) reken dat die paleisbou (1 Kon. 7:1-12/14) die sentrale punt van die hele narratief is. In teenstelling hiermee glo Porten (1967:107) dat die tempelwyding (1 Kon. 8:1-66) struktureel in die middel staan en die hoogtepunt van die Salomo-narratief is. Deist (1986:80) maak te veel van die chiastiese of 
Hoofstuk 8 is die langste hoofstuk in hierdie boek en vorm 'n afgebakende literêre eenheid. 1 Konings 8 begin in vers 1 met 'n verwysing na die samekoms van die volk en sluit af in vers 65-66

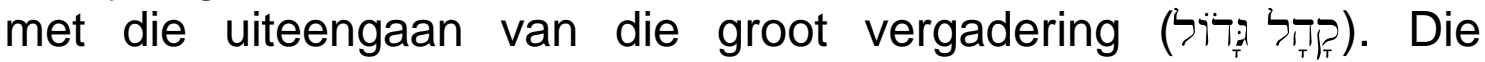
gebeure wat in 1 Konings 8 beskryf word, vind tussen hierdie twee momente plaas (Long, 1984:94). Verse 1-11 skets die bring van die verbondsark na die tempel in Jerusalem. 1 Konings 8:12 en 13 kan as deel van die toespraak van Salomo beskou word (vv. 14-21), omdat dit ingelei word met die woorde "Toe het Salomo gesê". Hierdie verse bestaan egter uit 'n unieke tempelwydingspreuk in die direkte rede terwyl vers 14 weer as inleiding dien vir die seën en verdere woorde van Salomo. Die Septuaginta plaas ook verse 12-13 ná vers 53. Weens bogenoemde redes word 1 Konings 8:12-13 as 'n aparte onderafdeling beskou.

Die gebed van Salomo (vv. 22-53) volg na Salomo se toespraak en kan as die kern van hierdie hoofstuk beskou word. Vers 22 dien as inleiding of oorgangsvers omdat dit aandui wie bid, waar hy bid en watter gebedshouding ingeneem word. Die sewe bedes onder verskillende omstandighede (vv. 31-51) kan weer as die kern van die gebed getipeer word. Hierdie omstandighede skets die totale of alomvattende bedreiging wat die bidder ervaar: bedreiginge in die natuur en die geskiedenis (Nelson, 1987:53). 'n Eenvoudige struktuur kom by al sewe bedes voor. By elkeen van die bedes word eers die omstandigheid/hede geskets en dan die smeking tot God waarin die volgende frase voorkom: "... wil $U$ dan hoor in die hemel ... en vergewe/optree/reg doen" (vv 32, 34, 36, 39, 43, 45 en 49) (Long, 1984:103; Talstra, 1987:86).

1 Konings 8 sluit af met seën en feesviering. Vers 54 dien as inleiding vir die seën wat in die direkte rede aangebied word. Verse 62-66 beskryf die groot fees wat die tempelwyding afsluit.

konsentriese struktuur. Hy "forseer" die struktuur om sodoende die tempelbou as sentrale moment te erken. Hoofstukke 5-8 óf 6-9:9 staan sentraal binne die hele narratief en die inwyding van die tempel ( 1 Kon. 8) vervul 'n baie belangrike rol (Frisch, 1991:10). Reeds vanaf 1 Konings 3:1-2 word uitgesien na die tempelwyding. Salomo se versoek om wysheid (3:5-14), sy uitoefening daarvan (3:16-18), sy administrasie (4:20) en sy besluit om die tempel te bou $(5: 21)$ vind byval by die skrywer/s van die boek. Eers ná Hoofstuk 8 hoor 'n mens die eerste negatiewe klanke by die skrywer. Die belofte van 'n ewige Dawidiese dinastie wat in 1 Konings as 'n beloning vir gehoorsaamheid gesien word $(2: 4,45 ; 3: 14$; 6:1213 en 8:25), kry ook 'n negatiewe klank by. In Hoofstuk 9:6-9 is daar byvoorbeeld 'n verwysing na die gevolge van ongehoorsaamheid (Wheeler, 1977:10). 
Die struktuur van 1 Konings 8 kan waarskynlik soos volg opgesom word:

- Vergadering en bring van die ark na die tempel in Jerusalem

- Tempelwydingspreuk: Magtige teenwoordigheid van Jahwe in die tempel

- Toespraak van Salomo

- Gebed van Salomo met sewe bedes vir verskillende omstandighede

- Salomo seën die volk

- Wydingsoffers en fees

\subsection{Kultiese Sitz im Leben}

Die inhoud en literêre konteks van 1 Konings 8 veronderstel 'n nabye verhouding met die tempel in Jerusalem (vgl. 2.1). Daar is talle verwysings na die tempel, verbondsark, altaar, offers en priesters. In 1 Konings 8 kom verskillende standpunte oor die betekenis en funksie van die tempel na vore. Verse 5 en 62-64 verwys na die offerpraktyk by die tempel, maar in die gebed van Salomo (vv 22-53) word 'n "ander standpunt" aangaande die funksie van die tempel gepropageer. In teenstelling met die siening dat die tempel 'n plek is waar geoffer word, word die tempel in 1 Konings 8:22-53 voorgestel as 'n plek waar gebid word.

'n Groot gedeelte van hierdie hoofstuk bestaan uit bedes om vergifnis (vgl. vv. 30, 34, 36, 39 en 50). Volgens Koch (1966:226) is die vergifnis die "Schlusspunkt einer kultischen Begehung, mit Reinigung und Besprengung eng zusammengehört". In hierdie boeterite behels die vergifnis van sonde die Goddelike woord deur middel van die priester. Die moontlikheid bestaan dat die vergifnistekste met 'n kultiese boeterite saamhang, maar daar word geen verdere inligting oor 'n moontlike rite verskaf nie.

\subsection{Samestelling en datering}

Daar is nie eenstemmigheid onder navorsers oor die samestelling en datering van 1 Konings 8 nie. Feitlik al die navorsers erken die teenwoordigheid van 'n voor-eksiliese bron en die aanwesigheid van priesterlike redigering in 1 Konings 8:1-13 (Long, 1984:94; Knoppers, 1995:230; Mulder, 1998:376). Noth (1981:4-11) dui aan dat die 
Deuteronomis op strategiese punte in die Deuteronomistiese geskiedwerk 'n redevoering invoeg om die voorafgaande periode in Israel se geskiedenis te verklaar. Volgens Noth was 1 Konings 8 een van hierdie belangrike redevoerings. Baie navorsers ondersteun Noth se siening van 'n eksiliese Deuteronomistiese redevoering. $\mathbf{5}$ Daar is navorsers wat in navolging van Cross (1973:274-289) betoog dat daar twee Deuteronomistiese redaksies is: 'n preeksiliese Deuteronomis (Dtr 1) en 'n post-eksiliese redaktor (Dtr 2) (vgl. Friedman, 1981:1-43; Nelson, 1981:69-73; McKenzie, 1991: 137-140). Sommige navorsers aanvaar die redaksionele teorie van Smend (1971:494-509) en deel die standpunt van 'n reeks eksiliese Deuteronomistiese redaksies en post-Deuteronomistiese byvoegings (vgl. Dietrich, 1972:74; Würthwein, 1977:95-96; Veijola, 1982:154; Jones, 1984:198). Laastens moet 'n mens verwys na navorsers wat die standpunt van 'n reeks redaksies ondersteun. De Vries (1985:121) onderskei ten minste drie lae in hierdie gedeelte: (1) vroeë bronne-materiaal; (2) die Deuteronomistiese oorname en uitbreiding daarvan; en (3) post-Deuteronomistiese uitbreidings en glosse. Talstra (1987:139-206) maak 'n deeglike diakroniese analise van 1 Konings 8:14-61 en verwys na pre-Deuteronomistiese gedeeltes; twee Dtr 1-redaksies, 'n eksiliese redaksie (Dtr 2) en 'n post-Deuteronomistiese redaksie. O'Brein (1989:151-157) beredeneer die standpunt ten gunste van 'n reeks pre-eksiliese, eksiliese en post-eksiliese Deuteronomistiese redaksies van 'n pre-eksiliese bron.

Dit is duidelik dat 1 Konings 8 'n lang ontwikkelingsproses deurloop het. Daar was nie net een skrywer nie, maar waarskynlik 'n aantal skrywers/redaktors met verskillende historiese kontekste. Die hoofstuk kommunikeer belangrike Deuteronomistiese temas, maar aan die ander kant kan 1 Konings 8 nie slegs as 'n Deuteronomistiese teks bestudeer word nie. Die finale vorm en inhoud het waarskynlik eers ná die Deuteronomistiese geskiedwerk ontstaan. 1 Konings 8 is belangrik vir die verstaan van Goddelike teenwoordigheid, omdat dit verskillende beskouings oor God bevat. Dit is belangrik om te probeer verstaan wat verskillende skrywers/redaktors oor God gedink het en wat hulle in verskillende historiese omstandighede ervaar het. Die verskillende perspektiewe wat in 1 Konings 8 voorkom, sal vervolgens bespreek word.

$5 \quad$ Vgl. Weinfeld (1972:35-36, 195-198); Levenson (1981:156-162); Long (1984:94108). 


\section{Perspektiewe op God se teenwoordigheid in 1 Konings 8}

\subsection{Die ark, tempel en wolk as simbole van God se teenwoordigheid}

Die Ou-Testamentiese mens wou graag God se teenwoordigheid ervaar. Hierdie soeke is gekompliseer deur die verbod op enige gesnede beeld waarin God se teenwoordigheid konkreet gesien kon word. In die $\mathrm{Ou}$ Testament is daar egter verskillende maniere waarop die mense gepoog het om God se teenwoordigheid te konkretiseer: die ark, die tempel; die wolk; die heilige lot; en andere. In 1 Konings 8 word na eersgenoemde drie verwys (Corvin, 1972: 171; Terrien, 1978:197-198).

1 Konings 8:1-11 getuig hoedat die verbondsark in die Allerheiligste van die tempel geplaas is. Die narratief word in vers 10 en 11 afgesluit waar die priesterlike teologie van heerlikheid die wolk en heerlikheid van God uitbeeld:

En toe die priesters uit die heiligdom uitgaan, het die wolk die huis van die Here vervul. En die priesters kon vanweë die wolk nie staan om diens te doen nie, want die heerlikheid van die Here (כבוֹד-י-הוָה) het die huis van die Here gevul.6

In die daaropvolgende tempelwydingspreuk (8:12-13)7 word gesê dat Salomo vir Jahwe 'n huis gebou het om vir ewig in te woon:

Die Here het gesê dat Hy in donkerheid wil woon. Vir seker het ek vir $U$ 'n woonhuis gebou, 'n vaste plek vir $U$ om ewig in te woon.

Tydens die woestyntyd, intog en Rigtertyd is die ark in die tent van ontmoeting geplaas en was dit die sentrale simbool van Jahwe se teenwoordigheid (vgl. Jos. 3-4, 6, 8:30-35; Rigt. 2:1, 20:27; ens.). Volgens die Bybelse getuienis het die ark geswerf vanaf Gilgal na Bet-el en na Silo (Jos. 18:1; 1 Sam. 1:3; 3:3) voordat dit deur die Filistyne gebuit is (1 Sam. 4). Gedurende Dawid se koningstyd is die ark na Jerusalem gebring (Hague, 1997:503). Die ark was gevolglik

6 Daar word uit die 1933/1953-Afrikaanse vertaling aangehaal tensy anders vermeld.

7 Dit is interessant om daarop te let dat die LXX hierdie tempelwydingspreuk teen die einde van die hoofstuk na v. 53 plaas (Mulder, 1998:376). Daar is ook heelwat standpunte aangaande die oorsprong en plasing van vv. 12-13 wat nie hier bespreek gaan word nie (vgl. Van den Born, 1965:235-244; Loretz, 1974:478-480). Dit is egter van belang dat hierdie verse na die teenwoordigheid van God verwys. 
in die pre-monargale en vroeë monargale 8 periode die belangrikste simbool van God se teenwoordigheid. Die deksel van die ark met sy gerubs is as God se troon beskou en die ark self as voetbank van die troon. Die verskil tussen die ark en die wolk is dat eersgenoemde meer op die "tasbare" vlak van God se teenwoordigheid lê, terwyl die wolk meer op die "bo-natuurlike" vlak lê (Haran, 1978:254; Hurowitz, 1992:267).

In vers 8 word verwys na die draaghoute van die ark wat so lank was dat dit van die voorkant van die binneste heiligdom gesien kon word. Die sigbare draaghoute was waarskynlik vir die besoeker 'n bewys van die aanwesigheid van die ark en van God se spesiale teenwoordigheid (Brongers, 1979:92). Vers 8 getuig verder dat die draaghoute "tot vandag toe" sigbaar is. Hierdie frase kan eenvoudig beteken dat die vers vóór die vernietiging van die tempel geskryf is. Die spesifieke taalgebruik word egter behou selfs al is Konings eers ná die vernietigings van die tempel finaal geredigeer. Vers 8 kan ook moontlik sinspeel op die toekoms waar so 'n sigbare teenwoordigheid weer 'n realiteit sal wees (Fretheim, 1999:53).

Die wolk (vv.10-11) is die beeld van die heerlikheid van Jahwe (כבוֹדי-יהוזה) en as sodanig 'n teken van God se teenwoordigheid. Verse 10-11 moet teen die agtergrond van Eksodus 13:21 en 40:3435 gelees word waar 'n wolk die tabernakel gevul het en Moses nie kon inkom nie vanweë God se heerlikheid (Gray, 1980:210; Jones, 1984:195; Fretheim, 1999:53). ${ }^{9}$ Die verwysing na die wolk en God se heerlikheid verskaf gesag aan die institusionele strukture. Dit dien as 't ware as 'n heilige "bedekking" vir Sion (Jes. 4:5-6) (Brueggemann, 1982:29).

1 Konings 8:1-13 wys op 'n verband tussen ark, wolk en tempel. Toe die ark in die tempel ingebring is, neem God besit van sy huis en word die tempel vervul deur die wolk (1 Kon. 8:10). Dieselfde het gebeur in die verhale van die woestyntyd met die tent van ontmoeting (Eks. 33:9; 40:34-35; Num. 12:4-10) (De Vaux, 1973: 186-187). Deur die bring van die ark na Jerusalem (2 Sam. 6:1 Kron. 15-16) en die plasing daarvan in die tempel in Jerusalem (1 Kon. 8:1-11) word die tempel in Jerusalem die kultiese middelpunt.

8 Welten (1979:169-183) wys ook daarop dat die ark saam met die tempel en Jerusalem belangrike temas in die teologie van die Kronis (na-eksilies) was.

9 In die antwoord op die gebed van Salomo (1 Kon. 9:1-9; 2 Kron. 7:12-22) is daar ook 'n verwysing na 'n verskyning van Jahwe aan Salomo, maar daar is geen sprake van 'n wolk nie. 
In vers 13 word gepraat van die tempel as 'n vaste plek. Hierdie vers toon ooreenkomste met 2 Samuel 7:2 waar Dawid vir die profeet Natan sê dat Hy 'n huis vir die Here wil bou:

Kyk tog, ek woon in 'n huis van sederhout, maar die ark van God woon binnekant 'n tentdoek.

Die oortuiging dat God in die tempel woon, kom dikwels in die Psalms voor (Ps. 27:4, 42:5; 76:3; 84 e.a.). Ondanks hulle voorbehoud ten opsigte van die kultus deel die profete dieselfde siening: Amos meld dat die Here uit Sion brul en sy stem uit Jerusalem laat hoor (Am. 1:2); Jesaja word in die tempel tot profeet geroep (Jes. 6:1-4); Jeremia waarsku dat die plek waar God se magtige teenwoordigheid regeer, nie verwerp sal word nie (Jer. 14:21). Die profete waarsku egter dat God se teenwoordigheid in die tempel 'n teken van genade is en teruggetrek sal word as die volk ontrou is (Jer. 7:1-15; 26:1-15; Eseg. 8-10) (De Vaux, 1973:187).

In 1 Konings 8:10 en 64 word die tempel as ירוזה (huis van Jahwe) getipeer. Nêrens in die Ou Testament verwys dit na ander kultiese plekke weg van die tempel in Jerusalem nie (Haran 1964:254). 10 Dit beklemtoon weer eens die feit dat Jerusalem (Sion) 'n belangrike rol vervul in die teologiese tradisie van die Ou Testament, veral in die Deuteronomistiese geskiedwerk en Kronieke (Williamson, 1982:28).11

Bogenoemde bespreking het aangetoon dat 1 Konings 8:1-13 'n spesieke siening oor die teenwoordigheid van God oordra. In hierdie verse word God as 't ware beperk tot die ark en die tempel in Sion (Jerusalem). Dié siening handel oor die statiese inwoning van God (vgl. O'Kennedy, 1989:102). Daar was egter kritiek teen bogenoemde standpunt. Reeds in 1 Konings 8:1-13 sien 'n mens spore van 'n moontlike Deuteronomistiese interpretasie. In 1 Konings 8:9 staan die volgende woorde:

10 Volgens Von Hummelhauer (1903:46) word nie net die tempel nie, maar ook die Dawidiese dinastie beskryf as 'n huis waarin Jahwe woon. Deur Dawid se nageslag leef, woon en regeer Jahwe.

11 Daar het 'n spesifieke teologie rondom Sion ontstaan: Sion as die stad Jerusalem waar die Dawidiese dinastie begrond is; Sion as die heilige berg, die sentrum van die skepping en ontmoetingsplek van hemel en aarde; Sion as die tempel, die woonplek van God. 'n Sionstradisie en Sionsteologie het ontwikkel wat veral in die profesieë van Jesaja (die profeet van Jerusalem) en in die Sionspsalms (vgl. 46, 48, 76 en 87) weerspieël word (Kraus, 1984:83; Ollenburger, 1987:15-17). 
Daar was niks in die ark nie as net die twee kliptafels wat Moses by Horeb daarin neergelê het, toe die Here 'n verbond met die kinders van Israel gesluit het by hulle uittog uit Egipteland.

Hierdie vers is byna ondenkbaar in die konteks van die bring van die ark na die tempel. Vers 9 is egter in ooreenstemming met die herinterpretasie van die betekenis van die ark. In Deuteronomium was die ark nie meer 'n simbool van Jahwe se teenwoordigheid nie, maar net 'n houer vir die twee tafels van die wet. Die ark het nou die wet bevat, wat die etiese basis gevorm het van die verbondsverhouding tussen Israel en Jahwe (Clements, 1965:96; Brueggemann, 1982:30). Die Deuteronomistiese interpretasie van die twee kliptafels (Deut. 10:5) staan in kontras met die priesterlike siening dat die ark ook manna en Aäron se staf bevat (Eks. 16:33; Num. 17:25 [10]).

Dit is verder belangrik om te besef dat die gebed van Salomo (1 Kon. 8:22-53) die Deuteronomistiese interpretasie van die tempel beklemtoon. Die tempel simboliseer nie meer die skakel tussen die natuurlike en bonatuurlike wêrelde nie. Dit is eerder 'n plek vir gebed (Clements, 1965:91-92; Levenson, 1981:164).

\subsection{God woon in die hemel}

1 Konings 8 verwys nie slegs na God wat op 'n baie spesiale manier in sy tempel teenwoordig is nie. In vers 27 word die vraag gestel: "Maar sou God werklik op die aarde woon?". Dit word beantwoord deur herhaaldelik daarop te wys dat God se woonplek in die hemel is (vgl. vv. 34, 36, 39, 43 en 49) $\mathbf{1 2}$.

Die Ou Testament beskryf God as die Allerhoogste en Heer van die hemelse leërskare. Die siening dat Jahwe in die hemel woon, is vir Eichrodt (1967:190) 'n natuurlike uitvloeisel van bogenoemde beskouinge. Volgens hom is daar genoegsame getuienis uit die tyd van die Rigters en vroeë monargie wat hierdie siening bevestig. In die tyd van die profete het hierdie siening verdere momentum verkry. Dit het egter tydens die Persiese periode 'n hoogtepunt bereik toe daar meer as ooit tevore na Jahwe as die God van die hemel verwys is (2 Kron. 36:23; Esra 1:2; 5:12; Neh. 1:4, e.a.). Daar bestaan gevolglik 'n moontlikheid dat die universalisme en dualisme van die Persiese godsdiens die siening oor die woonplek van God

12 In antwoord op die vraag in v. 27 word ook vermeld dat selfs die hoogste hemel God nie kan bevat nie. Vergelyk bespreking by 3.4. 
beïnvloed het (Corvin, 1972:119), maar dit kan nie met sekerheid bepaal word nie. Houtman (1993:362-363) reken dat die voorstelling van Jahwe wat in die hemel woon, in sowel die vroeëre as die latere tyd beklemtoon is.

Dit is interessant om daarop te let dat die uitdrukking "hoor in die hemel" vyf keer in die Kronieke-weergawe na "hoor uit (מן) die hemel" verander word (2 Kron. 6:25, 30, 33, 35, 39). Die Kronis meld dat God nie staties "in die hemel" is nie. God hoor en tree dinamies op "uit die hemel". Die wysiging kan toegeskryf word aan die Kronis se opvatting dat die tempel ' $n$ afbeelding is van die hemel, met ander woorde, die makrokosmos (hemel) word gereflekteer in die mikrokosmos (tempel). Hierdie wysiging kan verder verklaar word deur die siening van God se onbeperkte vryheid wat Hy nietemin inperk ter wille van die gebed. Hy is in die hemel maar het "ingewillig" om sy Naam in die tempel te plaas. Wanneer daar in die rigting van die tempel gebid word, sal Hy hoor en antwoord (2 Kron. 6:18-21) (Levenson, 1981:164; Johnstone, 1993:129).

Talstra (1987:168-170)13 vergelyk vers $29-30$ met die sewe bedes (vv. 31-51) en wys op 'n paar interessante feite. In vers 30 staan die volgende woorde:

En luister na die smeking van u dienaar en van u volk Israel, wanneer hulle na hierdie plek toe mag bid. Wil $U$ dan hoor in $u$ woonplek, die hemel, en (ver)hoor en vergewe (eie vertaling).

Vers 30 onderskei duidelik tussen die gebed van die koning en die volk "na hierdie plek toe", en die hoor daarvan deur God "in u woonplek" met apposisie (bystelling) "in die hemel". Die gebruik van apposisie sorg vir groter duidelikheid: die tempel is die plek vir gebed, en die hemel is die plek waar God woon en die gebed aanhoor. Dieselfde duidelikheid kan 'n mens nie lees in die

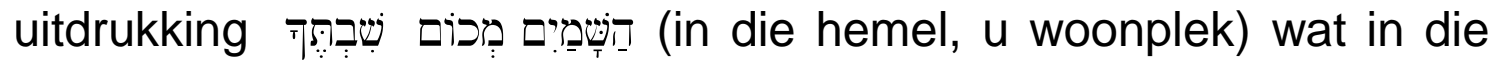
sewe bedes voorkom nie (vv. 39, 43, 49). By hierdie bedes word die

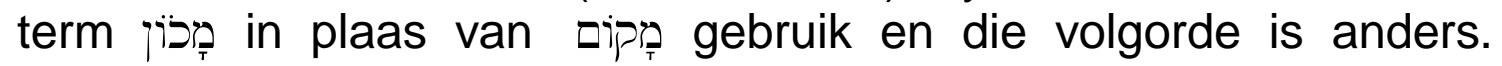
Talstra wys op interessante beklemtonings, maar dit verander niks aan die feit dat die teks van 1 Konings 8 onder andere na die hemel as God se woonplek verwys nie.

13 Talstra (1987:168-170) se vergelyking tussen v. 30 en die sewe bedes dien as begronding vir sy redaksie-historiese standpunte. Hy wys daarop dat die konstruksie van die uitdrukking "wil $U$ dan hoor in die hemel" wat in die sewe bedes voorkom, waarskynlik nie as Deuteronomisties getipeer kan word nie; ook nie die apposisionele uitdrukking "U woonplek" nie. 


\subsection{God se Naam is in die tempel}

1 Konings 8 verwys nie slegs na God wat in die ark of tempel woon óf God wat in die hemel woon nie. Die Deuteronomistiese tradisie het 'n teologie van Goddelike teenwoordigheid ontwikkel, die sogenaamde "Naamteologie". Hulle ontwikkel hierdie teologie in reaksie op die krisis van die vernietiging van die tempel in 586 v.C. waar die ballinge ver van die tempel moes bestaan14 (Ackroyd, 1980:28; Brueggemann, 1997:672). Die Deuteronomistiese "Naamteologie" het albei sienings oor God se teenwoordigheid (d.w.s. tempel en hemel) met mekaar versoen. God wat in die hemel woon, is teenwoordig in die tempel deur sy goddelike Naam (Weinfeld, 1972: 193; De Vries, 1985:128; Nelson, 1987:59).

Die uitroep van die Naam van Jahwe oor die tempel dui op twee moontlike betekenisse:

- Die uitroep van 'n naam oor iets of 'n gebied dui eerstens besit aan. 'n Klassieke voorbeeld hiervan is 2 Samuel 12:28: "... sodat ek nie die stad inneem en my naam daaroor uitgeroep word nie" (Burney, 1903:123). 'n Mens vind ook buite-Bybelse gegewens waar die veroweraar se naam uitgegraveer is, byvoorbeeld Ramses IV en Sisak by Megiddo.

- Die uitroep van die naam kan ook beteken dat die teenwoordigheid van die geroepe persoon aangedui word. In 1 Konings 8 kom laasgenoemde betekenis voor (Gray, 1980:225-226).

Die Deuteronomis het die betekenis van Jahwe se Naam ${ }^{15}$ beklemtoon; tog het die Naam van Jahwe voor die tyd van die Deuteronomis 'n teologiese inhoud gehad. In die kultus is die

14 Ná die vernietiging van die tempel het Israel twee maniere gevind om God se teenwoordigheid te formuleer wat nie net gebonde was aan die tempel in Jerusalem nie: (1) die priesterlike "teologie van heerlikheid"; en (2) die Deuteronomistiese "Naamteologie" (Brueggemann, 1997:671).

15 Daar word verskillende Name vir God in die Ou Testament gebruik, maar die belangrikste is die Naam Jahwe. Dit kom 6823 keer voor en word as die persoonlike Naam van die God van Israel beskou. Dit is die Naam wat aan die begin van die dekaloog voorkom ("Ek is Jahwe, jou God ...") en ook telkemale in 1 Konings 8. Daar is nie konsensus onder navorsers oor die oorsprong en betekenis van die woord nie. Eksodus 3:14 gee egter 'n definisie vir die Naam Jahwe: "Ek is wat Ek is". In hierdie artikel gaan nie in detail na die betekenis van die Naam Jahwe gekyk word nie. Die belangrikste is egter dat die Naam Jahwe op die lewende teenwoordigheid van God dui. Jahwe is die teenwoordige God wat homself openbaar as die God van Israel, die God van die vaders en as Skepper, Redder en Koning (Vriezen, 1966:372; Childs, 1986:38-39; Zimmerli, 1984:21-43). 
goddelike Naam byvoorbeeld gebruik by die offer, gebed, seën en vloek. Die priesters het die Naam van Jahwe oor die Israeliete uitgeroep wanneer hulle seën (Num. 6:27) en Jahwe se Naam het gefunksioneer tydens die neem van 'n eed (Von Rad, 1979:183). Die Naam van Jahwe word geassosieer met die groot verlossingsdade van God (Childs, 1986:39). Selfs onder die vreemdelinge (1 Kon. 8:42) sou die grote Naam verwys na God se teenwoordigheid en verlossingsmag.

Die vraag is: Wat is die verhouding tussen Jahwe en sy Naam? Was Jahwe self teenwoordig in die tempel? Daar is verskillende antwoorde op bogenoemde vrae. Aan die een kant is daar diegene wat ' $n$ afstand tussen Jahwe en sy Naam verkondig, terwyl ander navorsers wys op die eenheid tussen God en sy Naam:

- Vriezen (1966:226) wys daarop dat die Naam van Jahwe hom ten volle verteenwoordig, maar nie ten volle met hom geïdentifiseer kan word nie. Nicholson (1967:71) sê die volgende: "Not Yahweh himself but his name dwells in the sanctuary". Gray (1980:221) stel die afstand meer genuanseerd: "God's 'name' is the extension of his personality from the remote sphere which is the proper dwelling-place of the Lord transcendent (heaven)".

- Van der Woude (1976:957) se standpunt verskil van bogenoemde navorsers s'n. Hy meld dat die uitdrukking "die Naam van Jahwe" as wisselbegrip vir Jahwe in die Ou Testament gebruik word. Jahwe se Naam is in wese Jahwe self soos Hy in sy selfopenbaring teenwoordig is. Sy Naam is nie net die waarborg vir sy teenwoordigheid nie, maar tipeer sy persoonlike betrokkenheid by sy volk (Lev. 18:21; Am. 2:7; Eseg. 36:23).

Volgens Maly (1981:28-29) impliseer God se teenwoordigheid in die tempel nié dat Hy afwesig is in die res van die wêreld nie. God het egter die beperking van 'n aardse woonplek aanvaar. God self (d.i. gelyk aan sy Naam) is werklik in die tempel teenwoordig waar Israel Hom kan aanbid.

In Konings is die "Naam van Jahwe" die noemer waaronder die handelend teenwoordige Jahwe verstaan moet word. Die uitdrukking "'n huis vir die Naam van Jahwe" (1 Kon. 3:2; 5:3; 8:17, 19, 20, 44) stel die dade van Dawid, Salomo en Josia (2 Kon. 23:25) op 'n gelyke vlak met die vroeëre verlossingsgebeure onder die Naam van Jahwe. In 1 Konings 8 is die "huis wat ek vir U Naam gebou het" (8:48) die logiese uitvloeisel van "u volk en $u$ erfdeel, wat $U$ uit Egipte uitgelei het ..." (8:51). 


\subsection{God is alomteenwoordig}

Daar is reeds drie aspekte aangaande God se teenwoordigheid bespreek: Die ark, tempel en wolk as simbole van sy teenwoordigheid; God wat in die hemel woon; en God se Naam wat in die tempel woon. 'n Vierde kan hierby gevoeg word, naamlik die alomteenwoordigheid van God. Dit word nie pertinent in 1 Konings 8 gestel nie en kommentatore verleen nie veel aandag daaraan nie. Vers 27 dien waarskynlik as die beste beskrywing van God se alomteenwoordigheid:

Maar sou God werklik op die aarde woon? Kyk, die hemel, selfs die hoogste hemel kan U nie bevat nie; dan ook nie hierdie huis wat ek gebou het nie (eie vertaling).

In hierdie vers is daar drie dinge wat beklemtoon word:

- God woon nie net op aarde nie; die ark en tempel (huis van God) kan God nie inperk nie.

- God woon nie net in die hemel nie. Selfs die hoogste hemel kan Hom nie bevat nie.

- Die logiese konklusie van hierdie vers is dat God oral teenwoordig is: op die aarde, in die hemel en selfs tot in die hoogste hemel (Houtman, 1993:367).

Die woorde van vers 23a versterk waarskynlik die argument dat God alomteenwoordig is:

Jahwe, God van Israel, daar is geen God soos $U$ in die hemel daarbo of op die aarde hieronder nie (eie vertaling).

Hierdie vers beklemtoon die onvergelyklikheid en uniekheid van God, naamlik dat daar in die hemel en op die aarde nie nog 'n God soos Jahwe is nie. 'n Mens kan hieruit aflei dat die bidder as 't ware in die hemel en op aarde na 'n groter God gaan "soek" het, maar nie een kon kry nie. Sy God, Jahwe, is groter en magtiger as enige God wat op aarde en in die hemel is (Labuschagne, 1966:77, 122). Die unieke, onvergelyklike God is ook die alomteenwoordige God.

'n Laaste argument is dat die verskillende gebedsomstandighede God se alomteenwoordigheid veronderstel. In die meeste gevalle word genoem dat die volk in die rigting van die stad of tempel moet bid, maar dit sluit nie God se alomteenwoordigheid uit nie. Die bidder sien God as die alomteenwoordige tot wie hy kan bid: enige tyd (nag en dag: v.29); op enige plek (by die tempel, oorlogsveld of vreemde land); met enige krisis. 


\section{Gebed en God se teenwoordigheid}

Die bespreking in afdeling 3 het aangedui dat 1 Konings 8 verskillende perspektiewe op God se teenwoordigheid vir ons bied. Dit is reeds in afdeling 2 beredeneer dat die tempelwydingsgebed van Salomo (vv. 22-53) as die kern van hierdie hoofstuk beskou kan word. Die vraag is: Watter rol speel gebed in die siening oor God se teenwoordigheid? Hoekom kom soveel perspektiewe in die gebedsliteratuur voor?

Die bidder in 1 Konings 8 worstel met verskillende vrae: Waar woon God? Hoor God my gebed? Aan die ander kant sê gebed alreeds iets oor die teenwoordigheid van God. Die blote feit dat gebid word, wys daarop dat die bidder God as teenwoordige God erken en ervaar. Gebed impliseer ook dat daar 'n verhouding tussen God en mens en tussen God en die wêreld is. 'n Mens kan sê dat gebedsliteratuur die teologiese nadenke oor God se teenwoordigheid op die voorgrond plaas.

Daar is verskillende aspekte in God se verhouding met die wêreld. Fretheim (1984:37-44) wys op twee basiese perspektiewe wat 'n invloed het op die verstaan van die Goddelike teenwoordigheid:

- Die eerste aspek is die "ruimtelike werklikheid" van God se verhouding met die wêreld. In terme van die "ruimtelike werklikheid" getuig die Ou Testament van 'n tweedelige struktuur in die skepping. Hierdie struktuur word byvoorbeeld in Psalm 115:16 gekonseptualiseer:

Die hemel is hemele vir die Here, maar die aarde het Hy aan die mensekinders gegee."

Hierdie twee ruimtelike areas, hemel en aarde, beskryf die "domein" van God en mens respektiewelik. Met die oog op kommunikasie deur gebed moet daar een of ander wisselwerking plaasvind. Alhoewel daar van "aparte plekke" gepraat word, wys dit nie op ontoeganklikheid nie. In die gebed van Salomo (1 Kon. 8:22-53) word baie duidelik gestel dat God in die hemel die gebed van die mens (op aarde) sal hoor.

- Die tweede aspek handel oor God se verhouding tot tyd. Binne die skepping is God deel van temporele opeenvolging: verlede, hede en toekoms. Die Ou Testament bied egter verskillende perspektiewe op hierdie saak, veral die teksgedeeltes oor God se beplanning en voltrekking van oordeel (vgl. Jer. 18:11; 26:3; 49:20; Miga 2:3; 4:12; Ps. 103:9; 30:5; Jes. 54:7-8; e.a.). Hierdie 
gedeeltes maak net sin wanneer daar sprake is van God se beplanning van die oordeel, ' $n$ tyd van uitvoering van die oordeel en 'n tyd van verandering (bv. uitstel) of onttrekking van die oordeel.

Daar is gevolglik tussen die beplanning en uitvoering 'n tyd van "divine consultation" waar interaksie tussen God en mens kan plaasvind. Hierdie interaksie geskied deur die gebed. Die gebede om vergifnis vervul in hierdie "divine consultation" 'n belangrike rol (Balentine, 1993:38-39) (vgl. Gen. 18:7-22; Eks. 32:7-14; Num. 14: 11-20; 1 Kon. 8:22-53; Am. 7:1-6).

Ons het reeds vermeld dat 1 Konings 8 verwys na God wat in die hemel woon vanwaar Hy gebede hoor. Dit is nie slegs in 1 Konings 8 waar die hemelse woonplek in verband met gebed gebring word nie. Buiten 1 Konings 8 is daar talle voorbeelde (vgl. Deut. 26:15; Ps. 2:4; 14:2; 20:7; Jes. 63:15; Pred. 5:1; Klaagl. 3:41, 50; Dan. 4:31; Neh. 9:27; 2 Kron. 7:14; 20:6; 30:27; 32:20; e.a.). God is gelukkig nie staties in die hemel nie. Hy regeer, hoor gebede en tree dinamies op uit die hemel (Johnstone, 1993:129).

Op grond van bogenoemde bespreking kan 'n mens aflei dat gebed 'n belangrike rol in die siening oor God se teenwoordigheid vervul. Gebed is die manier waarop die tempel (plek waar gebid word) en die hemel (as die plek waar God woon en gebed aanhoor) mekaar ontmoet.

\section{Slot: samevattende gevolgtrekkings}

$\mathrm{Na}$ aanleiding van die probleemstelling en bogenoemde bespreking kan 'n mens 'n paar samevattende opmerkings maak:

- Die teks van 1 Konings 8 skep nie die indruk van 'n "battle for God's presence" soos Brueggemann (1982:27) dit tipeer nie. 'n Mens word eerder bewus van die veelkantigheid van God se teenwoordigheid. 1 Konings 8 het waarskynlik oor 'n lang tydperk gedurende verskillende historiese omstandighede ontstaan. Verskillende outeurs en redaktors was by die neerskryf en redigering van hierdie hoofstuk betrokke (vgl. 2.3); gevolglik vind 'n mens 'n verskeidenheid teologiese sieninge oor die teenwoordigheid van God:

- God en sy heerlikheid is op ' $n$ besondere wyse in die ark, tempel (huis van Jahwe) en wolk teenwoordig (vv. 1-13, 6364). 
- God woon in die hemel en luister na die gebede van gelowiges (vgl. vv. 30, 34, 36, 39, 43 en 49).

- Die Deuteronomistiese "Naamteologie" het albei sienings oor God se teenwoordigheid (d.w.s. tempel en hemel) met mekaar versoen. God wat in die hemel woon, is teenwoordig in die tempel deur sy goddelike Naam (vv. 16-20, 29, 44, 48).

- God is alomteenwoordig, selfs die hoogste hemel kan God nie vasvang nie (v. 27).

- Die teks van 1 Konings 8 lewer nie werklik 'n finale uitspraak oor watter perspektief "reg" is nie. Die finale redaktor het ook nie sekere sieninge weggelaat ten koste van ander nie. Die verskillende sieninge is eerder saamgevoeg in een hoofstuk. Hierdie verskillende perspektiewe kan die hoorder/leser verwar of die vraag laat ontstaan: Waar woon God regtig? Aan die ander kant beklemtoon die hoofstuk juis dat gelowiges nie slegs vanuit een perspektief na God se teenwoordigheid moet kyk nie. Daar is 'n geheimenis by God wat ons as mense op aarde nie altyd sal verstaan nie. Volgens 1 Konings 8 is Hy ook die onvergelyklike God (v. 23) wat met geen wese in die hemel of op aarde vergelyk kan word nie.

- Die grootste gedeelte van 1 Konings 8 bestaan uit die tempelwydingsgebed van Salomo (1 Kon. 8:22-53). Gebed en God se teenwoordigheid staan in 'n direkte verhouding met mekaar. Die blote feit dat gebid word, wys daarop dat die bidder God as teenwoordige God erken en ervaar. Gebed is die manier waarop die tempel (plek waar gebid word) en die hemel (as die plek waar God woon en gebed aanhoor) mekaar ontmoet. 1 Konings 8 beklemtoon dat gebed nie tot 'n ander belangrike of invloedryke persoon (soos bv. 'n koning) gerig word nie, maar tot die teenwoordige God wat luister en kan optree.

- Konings 8 toon aan dat sonde 'n skeiding tussen God en mens bring. Gelukkig is daar nie net sprake van sonde in hierdie hoofstuk nie, maar ook van vergifnis (vgl. vv. 30, 34, 36, 39, 50). Die Goddelike vergifnis is as 't ware die eerste "dwarsbalk" om hierdie skeiding tussen die teenwoordige God en die mens wat strewe na God se teenwoordigheid, te oorbrug (Staudt 1980: 254). Die vra van hierdie vergifnis geskied deur die gebed tot 'n alomteenwoordige en vergewensgesinde God. 


\section{Geraadpleegde bronne}

ACKROYD, P.R. 1980. Exile and restoration. London: SCM.

BALENTINE, S. 1993. Prayer in the Hebrew Bible. The drama of divine-human dialogue. Minneapolis: Fortress.

BRETTLER, M. 1991. The structure of 1 Kings 1-11. Journal for the Study of the Old Testament, 49:87-97.

BRONGERS, H.A. 1979. 1 Koningen. Tweede druk. Nijkerk: Callenbach. (De prediking van het Oude Testament.)

BRUEGGEMANN, W. 1982. 1 Kings. Atlanta: John Knox. (Knox Preaching Guides.)

BRUEGGEMANN, W. 1997. Theology of the Old Testament: Testimony, dispute, advocacy. Minneapolis: Fortress.

BURNEY, C.F. 1903. Notes on the Hebrew text of the books of Kings. Oxford: Clarendon.

CHILDS, B.S. 1986. Old Testament theology in canonical context. Philadelphia: Fortress.

CLEMENTS, R.E. 1965. God and temple. Oxford: Blackwell.

CORVIN, J.W. 1972. A stylistic and functional study of the prose prayers in the historical narratives of the Old Testament. Emory: Emory University. (Ph.D. Dissertation.)

CROSS, F.M. 1973. Canaanite myth and Hebrew epic: Essays in the history of religion of Israel. Cambridge: Harvard University Press.

DEIST, F.E. 1986. Verteltekste. (In Deist, F.E. \& Vorster, W.S., reds., Woorde wat ver kom. Kaapstad: Tafelberg. p. 69-102.)

DE VAUX, R. 1973. Hoe het Oude Israel leefde, Deel 2. Romen: Roermond.

DE VRIES, S.J. 1985. 1 Kings. Waco, Texas: Word Books. (Word Biblical Commentary.)

DIETRICH, W. 1972. Prophetie und Geschichte. Göttingen: VandenHoeck \& Ruprecht.

EICHRODT, W. 1967. Theology of the Old Testament. Vol. 2 (tr. by J.A. Baker). London: SCM.

FRETHEIM, T.E. 1984. The suffering God: An Old Testament perspective. Philadelphia: Fortress. (Overtures to Biblical theology.)

FRETHEIM, T.E. 1999. First and second Kings. Louisville, Kentucky: Westminster John Knox. (Westminster Bible Companion.)

FRIEDMAN, R.E. 1981. The exile and biblical narrative: The formation of the Deuteronomistic and priestly works. Chico, California: Scholars Press.

FRISCH, A. 1991. Structure and its significance: The narrative of Solomon's reign (1 Kings 1-12.24). Journal for the Study of the Old Testament, 51:314.

GRAY, J. 1980. I \& II Kings. 3rd. rev. ed. London: SCM. (Old Testament Library.)

HAGUE, S.T. 1997. S.v. ארו. New international dictionary of Old Testament theology and exegesis. Grand Rapids, Michigan: Zondervan. 1:500-510.

HARAN, M. 1964. The divine presence in the Israelite cult and the cultic institutions. Biblica, 50:251-267.

HARAN, M.1978. Temples and temple service in ancient Israel. Oxford: Clarendon.

HOUTMAN, C 1993. Der Himmel im Alten Testament: Israels Weltbild und Weltanschauung. Leiden: Brill. 
HUROWITZ, V.A. 1992. I have built you an exalted house. Temple building in the Bible in light of Mesopotamian and Northwest Semitic writings. Sheffield: Academic Press.

JONES, G.H. 1984. 1 and 2 Kings. Grand Rapids, Michigan: Eerdmans. (New Century Bible.)

JOHNSTONE, W. 1993. Solomon's prayer: Is intentionalism such a fallacy? Studia Theologica, 47:119-133.

KNOPPERS, G.N. 1995. Prayer and propaganda: Solomon's dedication of the temple and the Deuteronomist's program. Catholic Biblical Quarterly, 57:229-254.

$\mathrm{KOCH}$, K. 1966. Sühne und Sündenvergebung um die Wende von der exilischen zur nachexilischen Zeit. Evangelische Theologie, 26:217-239.

KRAUS, H-J. 1984. Theology of the Psalms. Minneapolis: Augsburg.

LABUSCHAGNE, C.J. 1966. The incomparability of Yahweh in the Old Testament. Leiden: Brill.

LEVENSON, J.D. 1981. From temple to synagogue: 1 Kings 8. (In Halpern, B. \& Levenson, J.D., eds. Traditions in transformation. Winona Lake: Eisenbrauns. p. 143-166.)

LONG, B.O. 1984. 1 Kings: with an introduction to historical literature. Grand Rapids: Eerdmans. (Forms of Old Testament Literature 9.)

LORETZ, O. 1974. Der Torso eines kanaanäisch-israelitisch Tempelweihspruches in $1 \mathrm{Kg} \mathrm{8,} \mathrm{12-13.} \mathrm{Ugarit-Forschungen,} \mathrm{6:478-480.}$

MALY, E. 1981. "The highest heavens cannot contain you": Immanence and transcendence in the Deuteronomist. (In Finkel, A. \& Frizzel, L., eds. Standing before God: Studies on prayer in scriptures and in tradition with essays in honor of John M. Oesterreicher. New York: Ktav Publishing House. p. 23-30.)

McKENZIE, S.L. 1991. The trouble with Kings: The composition of the book of Kings in the Deuteronomistic history. Leiden: Brill.

MULDER, M.J. 1998.1 Kings. Leuven: Peeters. (Historical Commentary on the Old Testament.)

NELSON, R.D. 1981. The double redaction of the Deuteronomistic history. Sheffield: JSOT.

NELSON, R.D. 1987. First and second Kings. Atlanta, Georgia: John Knox. (Interpretation.)

NICHOLSON, E.W. 1967. Deuteronomy and tradition. Oxford: Blackwell.

NOTH, M. 1981. The Deuteronomistic history. Sheffield: JSOT.

O'BRIEN, M.A. 1989. The Deuteronomistic history hypothesis: A reassessment. Göttingen: Vandenhoeck \& Ruprecht.

O'KENNEDY, D.F. 1989. Die gebed van Salomo: Riglyne vir die verstaan van gebed in die Ou Testament. Stellenbosch: Universiteit van Stellenbosch. (M.Th.-verhandeling.)

O'KENNEDY, D.F. 2000. The prayer of Solomon (1 Ki 8:22-53): Paradigm for the understanding of forgiveness in the Old Testament. Old Testament Essays, 13(1) 72-88.

OLLENBURGER, B.C. 1987. Zion the city of the great king: A theological symbol of the Jerusalem cult. Sheffield: JSOT.

PARKER, K.I. 1988. Repetition as a structuring device in 1 Kings 1-11. Journal for the Study of the Old Testament, 42:19-27.

PORTEN, B. 1967. The structure and the theme of the Solomon narrative (1 Kings 3-11). Hebrew Union College Annual, 38:93-128. 
SMEND, R. 1971. Das Gesetz und die Völker. Ein Beitrag zur deuteronomistischen Redaktionsgeschichte. (In Wolff, H.W., ed. Probleme biblischer Theologie. Gerhard von Rad zum 70. Geburtstag. München: Kaiser Verlag. p. 494-509.)

STAUDT, E. 1980. Prayer and the people in the Deuteronomist. Vanderbilt: Vanderbilt University. (Ph.D. dissertation.)

TALSTRA, E. 1987. Het gebed van Salomo: Synchronie en diachronie in de kompositie van 1 Kon. 8,14-61. Amsterdam: VU Uitgeverij.

TERRIEN, S.1978. The elusive presence: Toward a new biblical theology. San Francisco: Harper \& Row.

VAN DEN BORN, A. 1965. Zum Tempelweihespruch (1 Kg viii 12f). Oudtestamentische Studiën, 14:235-244.

VAN DER WOUDE, A.S. 1976. s.v. 'ש. Theologisches Handwörterbuch zum Alten Testament, 2:935-963.

VEIJOLA, T. 1982. Verheissung in der Krise. Studien zur Literatur und Theologie der Exilzeit anhand des 89 Psalm. Helsinki: Suomlainen Tiedeakatemia.

VON HUMMELHAUER, S.J. 1903. Salomons Tempelweihe. Biblische Zeitschrift, 1:43-46.

VON RAD, G. 1979. Old Testament theology. Vol. 1 (tr. by D.M.G. Stalker). 3rd. impression. London: SCM.

VRIEZEN, Th.C. 1966. Hoofdlijnen der theologie van het Oude Testament. Derde druk, opnieuw herzien en uitgebreid. Wageningen: Veenman \& Zonen.

WEINFELD, M. 1972. Deuteronomy and the Deuteronomic school. Oxford: Clarendon.

WELTEN, P. 1979. Lade-Tempel-Jerusalem: Zur Theologie der Chronikbücher. (In Gunneweg, A.H.J. \& Kaiser, O., hrsg. Textgemäss: Aufsätze und Beiträge zur Hermeneutiek des Alten Testaments. Göttingen: Vandenhoeck \& Ruprecht. p. 169-183.)

WHEELER, S.B. 1977. Prayer and the temple in the dedication speech of Solomon 1 Kings 8:14-61. Columbia: University of Columbia. (Ph.D. thesis.)

WILLIAMSON, H.G.M. 1982. 1 and 2 Chronicles. Grand Rapids, Michigan: Eerdmans. (New Century Bible.)

WÜRTHWEIN, E. 1977. Das Erste Buch der Könige: Kapitel 1-16. Göttingen: Vandenhoeck \& Ruprecht. (Das Alte Testament Deutch.)

ZIMMERLI, W. 1984. Old Testament theology in outline (tr. by D E Green). Edinburgh: Clark.

\section{Kernbegrippe:}

1 Konings 8: perspektiewe op Goddelike teenwoordigheid teenwoordigheid van God: ark, tempel, wolk gebed: ontmoetingspunt van aarde en hemel

\section{Key concepts:}

1 Kings 8: perspectives on divine presence presence of God: ark, temple, cloud prayer: meeting point of heaven and earth 
